\title{
Cellular aspects of the inhibitory actions of LH-RH on the ovary and testis
}

\author{
R. M. Sharpe \\ M.R.C. Reproductive Biology Unit, Centre for Reproductive Biology, 37 Chalmers Street, \\ Edinburgh EH3 $9 E W, U . K$.
}

It is now firmly established that LH-RH and its agonists can have direct inhibitory effects on gonadal function in male and female animals. The initial reaction to such findings was one of incredulity because they challenged one of the accepted 'truths' of endocrinology, namely that LH-RH was secreted only by hypothalamic neurones and acted only on the anterior pituitary. However, LH-RH, like other hypothalamic peptides (e.g. thyrotrophin-releasing hormone, somatostatin), is quite widely distributed throughout the body. Current evidence suggests that LH-RH-like peptides occur in spinal ganglia in the frog (Jan, Jan \& Kuffler, 1979; Jan, Jan \& Brownfield, 1980) and, in mammals, in the pineal gland (Wheaton, 1980), pancreas (Seppala, Wahlstrom \& Leppaluoto, 1979; Wahlstrom \& Seppala, 1979; Seppala \& Wahlstrom, 1980a), certain human mammary tumours (Seppala \& Wahlstrom, 1980b), the placenta (e.g. Khodr \& Siler-Khodr, 1980; Lee, Seppala \& Chard, 1981), ovary (Ying, Ling, Bohlen \& Guillemin, 1981) and testis (Sharpe, Fraser, Cooper \& Rommerts, 1981, 1982). In most of these instances the information available is restricted simply to a demonstration of the presence of LH-RH-like activity, but there is already considerable evidence as to the nature, function and mode of action of the locally produced peptide in the ovary and testis. As most of this information has been derived from the observed effects of LH-RH or its agonists when injected into rats, it is appropriate to begin by reviewing this evidence.

When LH-RH and its agonists are injected into intact or hypophysectomized male and female rats, the resultant inhibitory effects on gonadal function are strikingly similar. However, injection of large doses of $\mathrm{LH}$ and hCG also results in similar inhibitory changes. Therefore, in intact rats injected with $\mathrm{LH}-\mathrm{RH}$ agonists it is difficult to distinguish whether the observed changes reflect direct gonadal effects of the injected peptide or whether they are secondary to release of pituitary LH and perhaps FSH (for references and discussion see Labrie et al., 1980; Sharpe, 1980a). To avoid confusion this review will deal only with the reported gonadal effects of LH-RH and its agonists in vitro or in hypophysectomized animals. It is assumed that the results obtained under such conditions reflect in general the direct gonadal actions of LH-RH in the intact animal.

It should also be remembered that most of the studies discussed below have used agonistic LH-RH analogues (LH-RH agonists) rather than LH-RH itself. However, when both have been studied the effects have been identical except that 10- to 100-fold higher doses of LH-RH are required to produce effects comparable to those obtained using LH-RH agonists with substitutions at positions 6 and 10. This difference in potency is almost certainly a reflection of the greater susceptibility of LH-RH to enzymic breakdown (see Clayton \& Catt, 1981). For purposes of simplicity, the term LH-RH rather than LH-RH agonist(s) is subsequently used throughout this review, but the two terms are considered to be inter-changeable. 


\section{Direct effects of LH-RH on the ovary}

In the ovary, LH-RH affects granulosa and luteal cell function, and although there are also effects on the oocyte, these are probably mediated via the granulosa cells. The effects of LH-RH on these cells are predominantly inhibitory and are illustrated schematically in Text-fig. 1. The first evidence for such an effect centred on the dose-dependent inhibition by LH-RH of ovarian growth in immature hypophysectomized rats treated with hCG (Rippel \& Johnson, 1976), PMSG (Ying \& Guillemin, 1979) or FSH (Hsueh \& Erickson, 1979a). With such treatments ovarian growth results primarily from follicular growth, which is itself a consequence of increased oestradiol secretion by the proliferating granulosa cells. LH-RH exerts its effect on ovarian growth by blocking oestradiol secretion, and this is achieved by inhibition of the induction of both the aromatase enzyme and of LH receptors (Hsueh, Wang \& Erickson, 1980; see Text-fig. 1). Similarly, in cultures of rat granulosa cells, LH-RH causes dose-dependent inhibition of the FSH-induced increases in oestrogen and progesterone secretion (Hsueh \& Erickson, 1979a) and abolition of the increase in LH-receptor numbers (Hsueh et al., 1980); similar findings have been reported using cultures of porcine granulosa cells (Massicotte, Veilleux, Lavoie \& Labrie, 1980).

The ability of LH-RH to block oestrogen synthesis by granulosa cells may also be impaired at an earlier step because recent findings from cell cultures suggest that LH-RH can rapidly and irreversibly block LH-induced androgen secretion by the theca interstitial cells (Magoffin \& Erickson, 1981), and it is this androgen that acts exclusively as substrate for the aromatase enzyme in the granulosa cells (see Text-fig. 1).

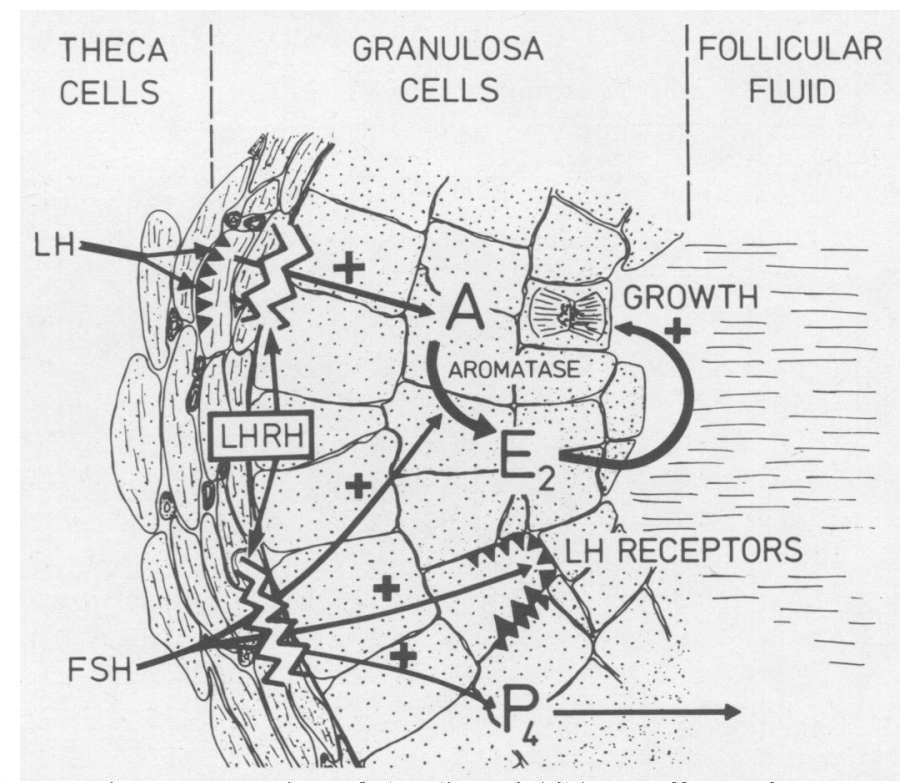

Text-fig. 1. Schematic representation of the direct inhibitory effects of LH-RH on theca cellgranulosa cell function in the rat ovary. Details are given in the text. A, androgens; $\mathrm{E}_{2}$, oestradiol; $\mathrm{P}_{4}$, progesterone; $\Delta, \mathrm{LH}$ receptors; +, positive stimulus.

These results suggest that LH-RH has inhibitory effects at several points in ovarian biochemical pathways but these remain to be pin-pointed. One clue is that the inhibitory effect of LH-RH on granulosa cell steroidogenesis is not restricted to antagonism of gonadotrophin action, because the stimulatory effects of dibutyryl cyclic AMP, cholera toxin and prostaglandin (PG) E-2 on steroidogenesis are all inhibited in vitro (Hsueh et al., 1980; Reddy, Azhar \& 
Menon, 1980). This suggests that LH-RH exerts its effect at some point beyond cyclic AMP stimulation, and measurement of gonadotrophin-stimulated cyclic AMP accumulation in incubations of rat granulosa cells substantiates this point (Reddy et al., 1980). However, the situation cannot be straightforward because, firstly, LH-RH has major effects on hormonestimulated cyclic AMP synthesis by luteal cells (see below) and, secondly, LH-RH does interfere partly with FSH-stimulated cyclic AMP synthesis in cultures of porcine granulosa cells (Massicotte et al., 1980). Indeed, recent evidence obtained with cultured rat granulosa cells suggests that LH-RH stimulates the activity of cyclic AMP phosphodiesterase, although this effect has an induction period of at least $24 \mathrm{~h}$ (Knecht, Katz, Amsterdam \& Catt, 1981).

The effects of LH-RH on rat granulosa cells are not exclusively inhibitory; the peptide has been shown to stimulate the secretion of PGE and to a lesser extent PGF in vitro, although this stimulation was not evident until 3-5 h after the start of incubation (Clark, Thibier, Marsh \& LeMaire, 1980). This particular effect may explain the ability of LH-RH to stimulate progesterone secretion and induce ovulation when administered on the morning of pro-oestrus to hypophysectomized PMSG-primed immature rats (Ekholm, Hillensjo \& Isaksson, 1981). Preovulatory changes in rat oocytes (meiotic maturation, germinal vesicle breakdown) can also be induced in vitro by exposure of follicle-enclosed rat oocytes to LH-RH (Hillensjo \& LeMaire, 1980). These stimulatory effects are particularly intriguing because they mimic the effects of LH on the preovulatory follicle, implying that LH-RH-like peptides produced within the ovary may normally mediate some of the effects of LH. The results also suggest that the stage of follicular development may determine whether LH-RH has an inhibitory or a stimulatory effect on granulosa cell steroidogenesis.

Once ovulation has occurred and the granulosa cells luteinize, the actions of LH-RH again become inhibitory. Thus LH- or hCG-stimulated progesterone secretion by rat luteal cells is inhibited in vitro by LH-RH (Clayton, Harwood \& Catt, 1979; Behrman, Preston \& Hall, 1980; Jones \& Hsueh, 1980), whilst the massive increases in progesterone secretion and luteal LH-receptor numbers evoked by prolactin in hypophysectomized rats induced to superovulate are obliterated by concomitant injection of LH-RH (Jones \& Hsueh, 1980). In the latter instance, prolactin stimulates progesterone secretion partly by antagonizing the action of the enzyme $20 \alpha$-hydroxysteroid dehydrogenase (20 $\alpha$-HSD), which converts progesterone to the inactive $20 \alpha$-hydroxy metabolite. In contrast, LH-RH stimulates the activity of $20 \alpha$-HSD and this partly explains its inhibition of progesterone secretion (Jones \& Hsueh, 1981).

However, the primary way in which LH-RH acts on luteal cells is by interfering with coupling of the LH-receptor complex to adenylate cyclase, thus impairing cyclic AMP generation and hence progesterone secretion (Clayton et al., 1979; Behrman et al., 1980). Interestingly, this action of LH-RH can be overcome by exposure of the luteal cells to high concentrations of $\mathrm{LH}$ or hCG, so that its effect is to cause a decrease in sensitivity to $\mathrm{LH}$ stimulation by shifting to the right the dose-response curves relating cyclic AMP and progesterone secretion to LH stimulation (Clayton et al., 1979; Behrman et al., 1980; Massicotte, Borgus, Lachance \& Labrie, 1981). A similar effect of LH-RH is observed when epinephrine rather than hCG is used to stimulate cyclic AMP and progesterone secretion (Harwood, Clayton \& Catt, 1980a). Although this interference by LH-RH with activation of adenylate cyclase is identical to the mode of action of PGF-2 $\alpha$ when inducing luteolysis, the effect of LH-RH is not prevented by the addition of indomethacin in vitro (Behrman et al., 1980; Hall \& Behrman, 1981). Nor is the action of LH-RH mediated by a change in LH-receptor numbers or in phosphodiesterase activity, and luteal progesterone secretion in response to stimulation with dibutyryl cyclic AMP is unaffected by LH-RH (Harwood et al., 1980a). This contrasts with the actions of LH-RH on granulosa cells described earlier.

One explanation for the above findings is that LH-RH binds to its receptor on the luteal cell surface (see below), and this hormone-receptor complex then negatively couples to adenylate cyclase, thus blocking the ability of the LH-receptor complex to couple positively with the 
cyclase enzyme (Massicotte et al., 1981). Whilst this possibility remains it should be emphasized that, to exert its inhibitory effect on the activation of adenylate cyclase, LH-RH must act on the intact cell rather than on isolated luteal membrane preparations (Behrman et al., 1980; Harwood et al., 1980a).

\section{Direct effects of LH-RH on the testis}

There are strong similarities between the effects of LH-RH on the testis and ovary; the actions of LH-RH on the testis, which are restricted to effects on the Leydig cell, are exclusively inhibitory and affect steroidogenesis and LH-receptor numbers. On the other hand, such effects have been demonstrated mainly in vivo, and no effect of LH-RH on short-term (1-48 h) incubations or cultures of Leydig cells have been observed, which contrasts with the ovary for which very rapid (10-180 $\mathrm{min})$ effects are achieved in vitro.

Treatment of hypophysectomized male rats with FSH stimulates Leydig cell function by increasing LH-receptor numbers and the capacity of the testis to secrete testosterone in response to LH or hCG (e.g. Chen, Payne \& Kelch, 1976; van Beurden, Roodnat, de Jong, Mulder \& van der Molen, 1976), and these effects are inhibited completely by concomitant treatment with LH-RH (Hsueh \& Erickson, 1979b). A similar inhibitory effect is observed when LH-RH is administered to otherwise untreated, hypophysectomized immature (Hsueh \& Erickson, 1979b) and adult (Bambino, Schreiber \& Hsueh, 1980) rats, results which were confirmed by Arimura, Serafini, Talbot \& Schally (1979) with respect to receptor numbers. Although the inhibition by LH-RH of the FSH-induced changes in the testis is exactly comparable to results obtained in the female (see earlier), there is a crucial difference in that the stimulatory action of FSH on Leydig cell function is an indirect effect mediated via the Sertoli cell by an unknown mechanism (see Sharpe, 1982). However, there are two reasons for concluding that LH-RH exerts its inhibitory action directly on the Leydig cell rather than via the Sertoli cell: (1) LH-RH receptors are present only on the Leydig cells within the testis (see below), and (2) LH-RH inhibits the ability of prolactin and growth hormone to increase Leydig cell LH-receptor numbers (Bambino et al., 1980), and both of these hormones act specifically on the Leydig cell.

The inhibitory effects of LH-RH on Leydig cell function are not immediate and results obtained in vivo suggest that exposure to LH-RH for 2 or more days is necessary for them to be seen (Bambino et al., 1980). This is consistent with the lack of effect of LH-RH on testosterone production during incubation of isolated Leydig cells (Badger et al., 1980; Sharpe et al., 1982), although Hsueh, Schreiber \& Erickson (1981) have shown complete inhibition of the hCG + FSH-stimulated androgen production by testicular cells cultured for more than 2 days in the presence of LH-RH.

Unlike the ovary, there is virtually no information as to how LH-RH exerts its inhibitory effects on Leydig cell function. Clearly, it does not interfere in the short term with coupling of the LH-receptor complex to adenylate cyclase as it does in luteal cells. However, LH-RH treatment in vivo does inhibit the activity of Leydig cell 17a-hydroxylase (Bambino et al., 1980), which may account for the decreased ability to secrete testosterone.

\section{Gonadal LH-RH receptors}

LH-RH exerts its effects on the ovary and testis via membrane receptors which show a similar specificity and affinity for LH-RH and its analogues as LH-RH receptors in the anterior pituitary (for comparisons, see Reeves, Seguin, Lefebvre, Kelly \& Labrie, 1980; Clayton \& Catt, 1981). Most studies on LH-RH receptors in the ovary have used ovarian homogenates but there is one demonstration of receptors on purified granulosa cells (Jones, Conn, Marian \& Hsueh, 
1980), and these are still present following luteinization (Clayton et al., 1979; Harwood et al., 1980a). Moreover, the ability of LH-RH to inhibit androgen secretion by theca interstitial cells in culture (Magoffin \& Erickson, 1981) suggests that these cells may also possess LH-RH receptors. In the testis, LH-RH receptors are present on the Leydig cells but not on cells within the seminiferous tubules (Bourne, Regiani, Payne \& Marshall, 1980; Clayton, Katikineni, Chan, Dufau \& Catt, 1980; Lefebvre, Reeves, Seguin, Massicotte \& Labrie, 1980; Perrin, Vaughan, Rivier \& Vale, 1980; Sharpe \& Fraser, 1980a). Further evidence that the actions of LH-RH on the gonads are mediated via stereospecific receptors is provided by the demonstration that antagonistic analogues of LH-RH prevent the gonadal actions of LH-RH in a dose-dependent manner (Hsueh \& Ling, 1979; Hsueh et al., 1981).

Already there is evidence that the number of gonadal LH-RH receptors may vary according to certain factors. For example, sequential treatment of hypophysectomized female rats with diethylstilboestrol, FSH, LH and prolactin results in a step-wise increase in the number of LH-RH receptors per ovary, although a progressive reduction is observed when the number of receptors is expressed on a per mg ovarian protein basis (Jones et al., 1980). The latter perhaps suggests that the number of LH-RH receptors per granulosa (luteal) cell decreases progressively during follicular development, but the fact that receptors were measured using whole ovarian tissue must render this interpretation speculative. In the male this problem is not encountered because isolated Leydig cells can be studied, and the results indicate that the number of LH-RH receptors per Leydig cell increases progressively from immaturity through puberty to adulthood (Text-fig. 2). Although it is tempting to speculate that this change bears some relationship to the marked change in activities of various steroidogenic enzymes which occur over the same time period (see Sharpe, 1982, for review), it is not yet known what significance to attach to the change in receptor numbers. Some hormones negatively regulate their own receptors (e.g. LH) whereas others may positively regulate their receptors (e.g. prolactin), and therefore the observed increase in LH-RH receptors on Leydig cells during sexual maturation could mean that the Leydig cells are exposed to increasing or decreasing levels of 'LH-RH'.
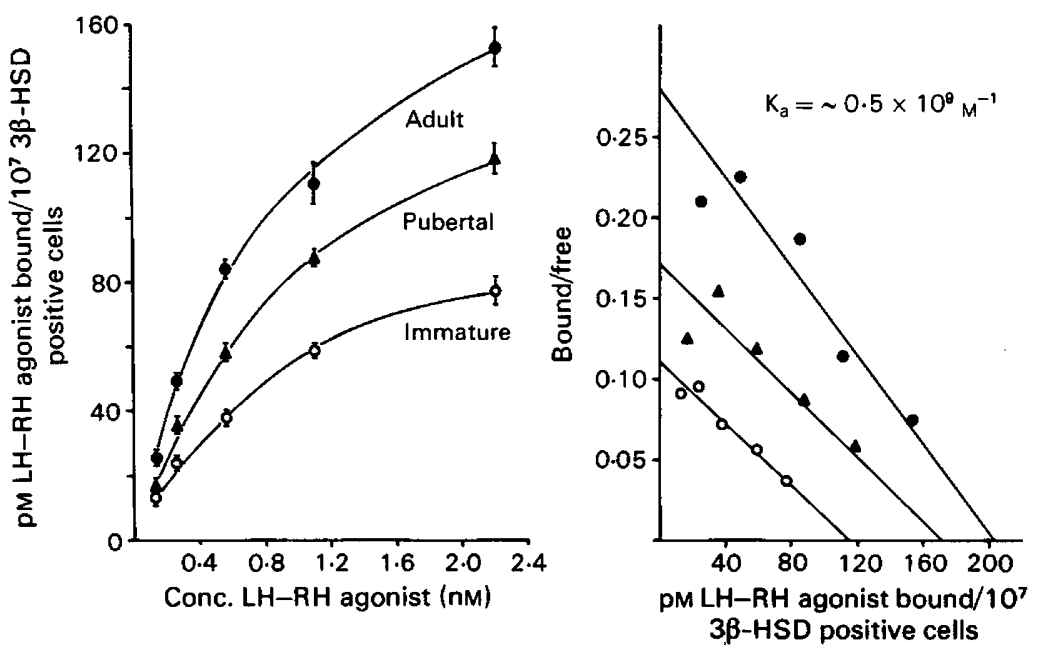

Text-fig. 2. Age-related increase in Leydig cell LH-RH-receptor numbers. Binding of ${ }^{125} \mathrm{I}$-labelled LH-RH agonist to isolated Leydig cells ( $3 \beta$-HSD positive) from rats aged 30 (immature), 60 (pubertal) or 100 (adult) days was assessed as described by Sharpe \& Fraser (1980a), and the results are given as (a) a saturation curve and (b) a Scatchard plot. Each point is the mean \pm s.d. of 3 incubations and results are representative of 2 experiments. 
However, one interesting finding is that treatment of rats with hCG causes a reduction in the number of LH-RH receptors in both the ovary (Harwood, Clayton, Chen, Knox \& Catt, 1980b) and testis (Table 1). This reduction occurs over the same time period as the reduction ('down-regulation') in number of LH (hCG)-receptors (Table 1), and is relevant because of the reported increase in the intratesticular secretion of an LH-RH-like factor following injection of hCG (see below).

Table 1. hCG-induced decrease in Leydig cell LH-RH-receptor numbers in adult rats

\begin{tabular}{ccccc}
\hline \multirow{2}{*}{$\begin{array}{c}\text { Dose of } \\
\text { hCG injected } \\
\text { (i.u.) }\end{array}$} & $\begin{array}{c}\text { Hours } \\
\text { after } \\
\text { injection }\end{array}$ & $\begin{array}{c}\text { LH-RH receptors } \\
\text { pM LH-RH agonist bound/107 }\end{array}$ & \% of Control & $\begin{array}{c}\text { LH receptors } \\
\text { (\% of control) }\end{array}$ \\
\hline 0 & 48 & $262 \cdot 2 \pm 25 \cdot 0$ & $(100)$ & $(100)$ \\
50 & 48 & $57.7 \pm 13.3$ & $22^{*}$ & $16^{*}$ \\
0 & 65 & $221.5 \pm 11.0$ & $(100)$ & $(100)$ \\
150 & 65 & $47.4 \pm 7 \cdot 5$ & $21^{*}$ & $9^{*}$ \\
30 & 65 & $82.5 \pm 3 \cdot 5$ & $37^{*}$ & $21^{*}$ \\
6 & 65 & $216.0 \pm 15.5$ & 98 & $63^{*}$ \\
\hline
\end{tabular}

Binding of ${ }^{125}$ I-labelled LH-RH agonist was performed as described by Sharpe \& Fraser (1980a) using collagenase dispersed Leydig cells. The results (mean \pm s.d., $n=3$ ) were obtained by Scatchard analysis and are representative of 2 or more experiments. The change in the number of LH receptors is shown for comparison, and this and staining for $3 \beta$-HSD were assessed as described by Sharpe \& McNeilly (1980). ${ }^{*} P<0.001$ in comparison with respective control group.

\section{Gonadal LH-RH-like peptides}

The presence of LH-RH receptors in the gonads and the multiplicity of LH-RH actions on the gonads raises the important question of the physiological significance of these findings. Unquestionably, LH-RH from the hypothalamus never reaches the gonads in effective amounts, implying that LH-RH or an LH-RH-like peptide is produced locally within the gonads. Indeed, the pattern of binding of ${ }^{125}$ I-labelled LH-RH agonists to isolated Leydig cells at different temperatures is indicative of a system geared to the detection and rapid inactivation of a locally produced factor (Sharpe et al., 1982), and there is now clear evidence in support of this contention.

Acetic acid extracts of ovarian (Ying et al., 1981) and testicular tissue (Sharpe et al., 1981, 1982) both contain LH-RH-like biological activity, as shown by their ability to stimulate pituitary gondaotrophin release in vitro and, in the case of the testis, to compete for binding to the Leydig cell LH-RH receptor. In the ovary the source of this material is believed to be the granulosa cells which secrete the peptide into follicular fluid, from which it can be extracted (Ying et al., 1981). Similarly, the Sertoli cell appears to be the source of the LH-RH-like material in the testis, and small amounts of this peptide are secreted in vitro by cultures of Sertoli cells (Sharpe et al., 1981, 1982).

These gonadal LH-RH-like factors are clearly different from hypothalamic LH-RH. For example, ovarian 'LH-RH' (gonadocrinin), which has been purified to a considerable extent, is 2 to 3-times the molecular size of hypothalamic LH-RH and is not detectable by conventional LH-RH radioimmunoassays (Ying et al., 1981). Similarly, the comparable factor from the testis, which as yet has only been characterized in crude extracts, does not generally cross-react in LH-RH radioimmunoassays (Text-fig. 3), but does cross-react in parallel with an LH-RH agonist standard in a radioimmunoassay specific for the LH-RH agonist (Text-fig. 4) and in which native LH-RH shows minimal cross-reaction. 


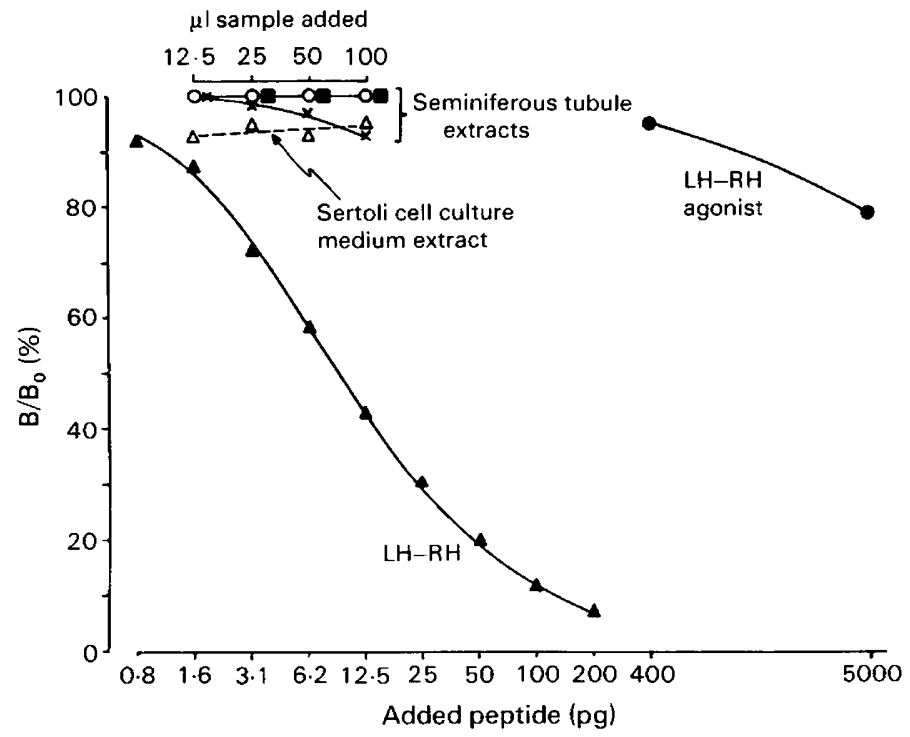

Text-fig. 3. Absence of cross-reaction of acid/ethanol extracts of rat seminiferous tubules or Sertoli cell culture medium in a conventional radioimmunoassay for LH-RH.

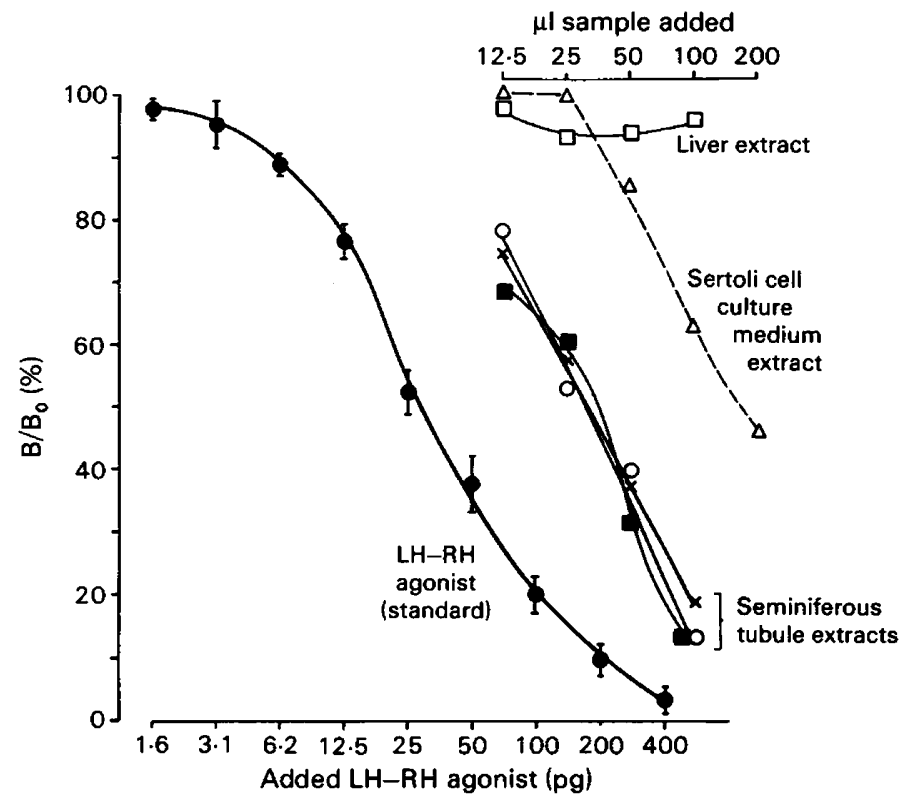

Text-fig. 4. Cross-reaction of acid/ethanol extracts of rat liver, seminiferous tubules or Sertoli cell culture medium in a radioimmunoassay for an LH-RH agonist, and in which natuve LH-RH shows $<0.1 \%$ cross-reaction.

\section{The physiological function of gonadal LH-RH-like peptides}

The physiological role of these gonadal peptides is as yet uncertain, and although it is reasonable to assume that their actions will be identical to the effects of injected LH-RH described earlier, this remains to be proved directly. However, to summarize this evidence for the ovary (Text-fig. 1), it suggests that ovarian 'LH-RH' is a potent inhibitor of ovarian steroidogenesis both in the developing and post-ovulatory follicle, although its actions may be different in the immediately 
preovulatory follicle. Therefore, because of its rapid and comprehensive inhibitory effect on granulosa and luteal cell function, it seems likely that ovarian 'LH-RH' may have an important role to play in processes such as follicular atresia and luteal regression, and perhaps also in regulating which follicles will develop. As these are fundamental events in normal ovarian function, it may prove that ovarian ' $\mathrm{LH}-\mathrm{RH}$ ' is of central importance in the regulation of the ovary.

Although it is less easy to ascribe a role to testicular ' $\mathrm{LH}-\mathrm{RH}$ ', there is considerable background information which suggests that the Sertoli cells produce one or more factors which have effects on Leydig cell function, and it is worthwhile considering these data in relation to the known effects of LH-RH on the Leydig cell. There are two separate areas of information, the effects of FSH and the effects of seminiferous tubule damage.

Treatment of hypophysectomized immature male rats with FSH stimulates Leydig cell function by causing an increase in $\mathbf{L H}$-receptor numbers and in the capacity to secrete testosterone in response to stimulation by LH or hCG (e.g. Chen et al., 1976; van Beurden et al., 1976; for review, see Sharpe, 1982). Because FSH receptors are restricted to the Sertoli cells (Means, 1977), these effects of FSH on the Leydig cell must be mediated by a factor which is secreted by the Sertoli cells and acts on the Leydig cells. The nature of this factor is unknown but it could be a stimulator of Leydig cell growth and/or function whose secretion is enhanced by FSH or, llike 'LH-RH', it could be an inhibitor of the Leydig cells which is secreted in reduced amounts after treatment. Secondly, when seminiferous tubule damage is induced in adult rats by a variety of techniques (cryptorchidism, local heating, $\mathrm{X}$-irradiation, hydroxyurea treatment, vitamin A deficiency), there is associated hypertrophy and/or hyperplasia of the Leydig cells (e.g. Kerr et al., 1979a; Rich and de Kretser, 1979; Rich, Kerr \& de Kretser, 1979). However, as there is also an increase in the blood levels of LH and FSH in these instances, it can be argued that the Leydig cell changes are secondary to this change. This possibility is lessened by the observation that induction of seminiferous tubule damage unilaterally results in Leydig cell hypertrophy only in the damaged testis and not in the contralateral 'normal' testis (Risbridger, Kerr \& de Kretser, 1981; Risbridger, Kerr, Peake \& de Kretser, 1981), and this occurs even though blood flow to the damaged testis is subnormal (Main \& Setchell, 1980). But perhaps the most convincing evidence for a local cause of these Leydig cell changes comes from a study by Aoki \& Fawcett (1978), who implanted threads impregnated with anti-androgens locally within the testis of the adult rat. This resulted in local atrophy of the seminiferous tubules around the implants and, associated with this change, there was marked hypertrophy and hyperplasia of the Leydig cells. These changes were not observed elsewhere in the implanted testis or in the contralateral testis.

Therefore, these findings suggest that, following the induction of seminiferous tubule damage in the adult rat, a gonadotrophin-independent increase in Leydig cell size and/or numbers may occur. Two possible, but opposing, explanations for these changes would be that the Sertoli cells secrete more of a 'Leydig cell-stimulating factor' following seminiferous tubule damage or that they secrete less of a 'Leydig cell-inhibiting factor'. Although either or both possibilities may be correct, the only evidence available favours the latter. Firstly, because the secretory function of the Sertoli cells is known to be impaired when there is seminiferous tubule damage (Hagenas \& Ritzén, 1976; Kerr et al., 1979b) and, secondly, because the Sertoli cells secrete an LH-RH-like factor which appears to be an inhibitor of Leydig cell function.

There are two other pieces of evidence which would support this interpretation. The first concerns the inhibitory effects of hCG on Leydig cell function. After injection of high doses of hCG, Leydig cell function is impaired transiently, a change which first becomes evident at about 12-16 h after injection (e.g. Sharpe, 1980b). At the same time increased levels of an LH-RH-like factor become detectable in the interstitial fluid that bathes the Leydig cells, and separates them from the seminiferous tubules (Sharpe \& Fraser, 1980b). This raises the possibility that the inhibitory effects of hCG on Leydig cell function are mediated by the local secretion of this 
factor from the Sertoli cells. This possibility is strengthened by the observation that immunological neutralization of this LH-RH-like factor in vivo can partly prevent the inhibitory effects of hCG on Leydig cell function (Sharpe et al., 1982).

If this interpretation is correct then the missing link in the loop is the factor that is secreted by the Leydig cells in response to hCG, which subsequently acts on the Sertoli cells to stimulate secretion of the LH-RH-like peptide. As yet, the only known candidate for such a role is testosterone, and indeed all the available information suggests that testosterone does have negative feedback effects on Leydig cell function (Purvis, Clausen \& Hansson, 1979; Adashi \& Hsueh, 1981). Also, the findings of Aoki \& Fawcett (1978) are again relevant, as they observed Leydig cell hyperplasia around implants of anti-androgens and it is possible that the Leydig cell changes were secondary to blockade of androgen action on the Sertoli cell rather than to the associated seminiferous tubule damage.

Putting this information together with the known inhibitory effects of LH-RH on the Leydig cell, a scheme of Sertoli cell-Leydig cell interaction can be postulated in which 'LH-RH' from the Sertoli cells normally keeps the Leydig cells under inhibitory restraint. In this scheme it is suggested that FSH inhibits whilst testosterone stimulates the secretion of the peptide and that it is the balance between these two stimuli which determines the level of secretion of 'LH-RH'. However, it should be remembered that both of these links are entirely hypothetical, and the proposed model is offered as a basis for future investigation rather than as a definitive scheme. It should also be emphasized that the action of ' $\mathrm{LH}-\mathrm{RH}$ ' in this model is to alter LH-receptor numbers and the steroidogenic capacity of the Leydig cells and thereby to modify the ability of the cells to respond to $\mathrm{LH}$.

Perhaps the most attractive feature of the proposed scheme is that it makes sound physiological sense. Because spermatogenesis and hence fertility are so critically dependent on androgens from the Leydig cell which act through the Sertoli cell (see Hansson, Calandra, Purvis, Ritzen \& French, 1976; Means, Fakunding, Huckins, Tindall \& Vitale, 1976), it is logical that the latter should have some means of regulating how much testosterone they receive from the Leydig cells.

\section{Conclusions}

This review has shown that LH-RH and its agonists have direct and principally inhibitory effects on steroidogenesis in both the ovary and testis. These effects of exogenous LH-RH are taken to reflect the physiological actions of LH-RH-like peptides produced locally within the gonads. These peptides may be important in the regulation of follicular development and atresia and luteal regression in the ovary, and as a means of communication between the Sertoli and the Leydig cells in the testis.

\section{References}

Adashi, E.Y. \& Hsueh, A.J.W. (1981) Autoregulation of androgen production in primary culture of rat testicular cells. Nature, Lond. 243, 737-738.

Aoki, A. \& Fawcett, D.W. (1978) Is there a local feedback from the seminiferous tubules affecting activity of the Leydig cell? Biol. Reprod. 19, 144-158.

Arimura, A., Serafini, P., Talbot, S. \& Schally, A.V. (1979) Reduction of testicular luteinizing hormone/ human chorionic gonadotropin receptors by (DTrp ${ }^{6}$ )-luteinizing hormone releasing hormone in hypophysectomized rats. Biochem. Biophys. Res. Commun. 90, 687-693.

Badger, T.M., Beitins, I.Z., Ostrea, T., Crisafulli, J.M.,
Little, R. \& Saidel, M.E. (1980) Luteinizing hormone-releasing hormone does not inhibit testosterone production in rat interstitial cells in vitro. Endocrinology 106, 1149-1153.

Bambino, T.H., Schreiber, J.R. \& Hsueh, A.J.W. (1980) Gonadotropin-releasing hormone and its agonist inhibit testicular luteinizing hormone receptor and steroidogenesis in immature and adult hypophysectomized rats. Endocrinology 107, 908-917.

Behrman, H.R., Preston, S.L. \& Hall, A.K. (1980) Cellular mechanism of the antigonadotropic action of luteinizing hormone-releasing hormone in the corpus luteum. Endocrinology 107, 656-664.

Bourne, G.A., Regiani, S., Payne, A.H. \& Marshall, J.C. 
(1980) Testicular GnRH receptors-characterization and localization on interstitial tissue. J. clin. Endocr. Metab. 51, 407-409.

Chen, Y.D.I., Payne, A.H. \& Kelch, R.P. (1976) FSH stimulation of Leydig cell function in the hypophysectomized immature rat. Proc. Soc. exp. Biol. Med. 153, 473-475.

Clark, M.R., Thibier, C., Marsh, J.M. \& LeMaire, W.J. (1980) Stimulation of prostaglandin accumulation by luteinizing hormone-releasing hormone (LHRH) and LHRH analogs in rat granulosa cells in vitro. Endocrinology 107, 17-23.

Clayton, R.N. \& Catt, K.J. (1981) Gonadotrophinreleasing hormone receptors: characterization, physiological regulation and relationship to reproductive function. Endocr. Rev. (in press).

Clayton, R.N., Harwood, J.P. \& Catt, K.J. (1979) Gonadotrophin-releasing hormone analogue binds to luteal cells and inhibits progesterone production. Nature, Lond. 282, 90-92.

Clayton, R.N., Katikineni, M., Chan, V., Dufau, M.L. \& Catt, K.J. (1980) Direct inhibition of testicular function by gonadotropin-releasing hormonemediation by specific gonadotropin releasing hormone receptors in interstitial cells. Proc. natn. Acad. Sci., U.S.A. 77, 4459-4463.

Ekholm, C., Hillensjo, T. \& Isaksson, O. (1981) Gonadotropin releasing hormone agonists stimulate oocyte meiosis and ovulation in hypophysectomized rats. Endocrinology 108, 2022-2024.

Hagenas, L. \& Ritzén, E.M. (1976) Impaired Sertoli cell function in experimental cryptorchidism. Molec, cell. Endocr. 4, 25-35.

Hall, A.K. \& Behrman, H.R. (1981) Culture sensitization and inhibition of luteinizing hormone responsive production of cyclic AMP in luteal cells by luteinizing hormone, prostaglandin $\mathrm{F} 2 \alpha$ and $\left(\mathrm{D}-\operatorname{Trp}^{6}\right.$ )-luteinizing hormone releasing hormone. $J$. Endocr. 88, 27-38.

Hansson, V., Calandra, R., Purvis, K., Ritzén, M. \& French, F.S. (1976) Hormonal regulation of spermatogenesis. Vitams Horm. 34, 187-214.

Harwood, J.P., Clayton, R.N. \& Catt, K.J. (1980a) Ovarian gonadotropin-releasing hormone receptors. 1. Properties and inhibition of luteal cell function. Endocrinology 107, 407-413.

Harwood, J.P., Clayton, R.N., Chen, T.T., Knox, G. \& Catt, K.J. (1980b) Ovarian gonadotropin-releasing hormone receptors. 2. Regulation and effects on ovarian development. Endocrinology 107, 414-421.

Hillensjo, T. \& LeMaire, W.J. (1980) Gonadotrophin releasing hormone agonists stimulate meiotic maturation of follicle-enclosed rat oocytes in vitro. Nature, Lond. 287, 145-146.

Hsueh, A.J.W. \& Erickson, G.F. (1979a) Extrapituitary action of gonadotropin-releasing hormone: direct inhibition of ovarian steroidogenesis. Science, N.Y. 204, 854-855.

Hsueh, A.J.W. \& Erickson, G.F. (1979b) Extra-pituitary inhibition of testicular function by luteinizing hormone releasing hormone. Nature, Lond. 281, 66-67.

Hsueh, A.J.W. \& Ling, N.C. (1979) Effect of an antagonistic analog of gonadotropin releasing hormone upon ovarian granulosa cell function. Life Sci. 25, 1223-1230.
Hsueh, A.J.W., Wang, C. \& Erickson, G.F. (1980) Direct inhibitory effect of gonadotropin-releasing hormone upon follicle-stimulating hormone induction of luteinizing hormone receptor and aromatase activity in rat granulosa celis. Endocrinology 106, 1697-1705.

Hsueh, A.J.W., Schreiber, J.R. \& Erickson, G.F. (1981) Inhibitory effect of gonadotropin releasing hormone upon cultured testicular cells. Molec. cell. Endocr. 21, 43-49.

Jan, L.Y., Jan, Y.N. \& Brownfield, M.S. (1980) Peptidergic transmitters in synaptic boutons of sympathetic ganglia. Nature, Lond. 288, 380-382.

Jan, Y.N., Jan, L.Y. \& Kuffier, S.W. (1979) A peptide as a possible transmitter in sympathetic ganglia of the frog. Proc. natn. Acad. Sci., U.S.A. 76, 1501-1505.

Jones, P.B.C. \& Hsueh, A.J.W. (1980) Direct inhibitory effect of gonadotropin-releasing hormone upon luteal luteinizing hormone receptor and steroidogenesis in hypophysectomized rats. Endocrinology 107, 1930-1936.

Jones, P.B.C. \& Hsueh, A.J.W. (1981) Direct stimulation of ovarian progesterone-metabolizing enzyme by gonadotropin-releasing hormone in cultured granulosa cells. J. biol. Chem. 256, 12481254.

Jones, P.B.C., Conn, P.M., Marian, J. \& Hsueh, A.J.W. (1980) Binding of gonadotropin releasing hormone agonist to rat ovarian granulosa cells. Life Sci. 27, 2125-2132.

Kerr, J.B., Rich, K.A. \& de Kretser, D.M. (1979a) Alterations of the fine structure and androgen secretion of the interstitial cells in the experimentally cryptorchid rat testis. Biol. Reprod. 20, 409-422.

Kerr, J.B., Rich, K.A. \& de Kretser, D.M. (1979b) Effects of experimental cryptorchidism on the ultrastructure and function of the Sertoli cells and peritubular tissue of the rat testis. Biol. Reprod. 21, 823-838.

Khodr, G.S. \& Siler-Khodr, T.M. (1980) Placental luteinizing hormone-releasing factor and its synthesis. Science, N.Y. 207, 315-317.

Knecht, M., Katz, M., Amsterdam, A. \& Catt, K. (1981) Stimulation of granulosa cell differentiation by FSH and 8-bromo cAMP and its inhibition by a GnRH agonist. Endocrinology 108, Suppl. p. 162, Abstr. 319.

Labrie, F., Belanger, A., Cusan, L., Seguin, C., Pelletier, G., Kelly, P., Reeves, J.J., Lefebvre, F.-A., Lemay, A., Gourdeau, Y. \& Raynaud, J.-P. (1980) Antifertility effects of LHRH agonists in the male. $J$. Androl. 1, 209-228.

Lee, J.N., Seppala, M. \& Chard, T. (1981) Characterization of placental luteinizing hormone-releasing factor-like material. Acta endocr., Copenh. 96, 394-397.

Lefebvre, F.-A., Reeves, J.J., Seguin, C., Massicotte, J. \& Labrie, F. (1980) Specific binding of a potent LHRH agonist in rat testis. Molec. cell. Endocr. 20, 127-134.

Magoffin, D.A. \& Erickson, G.F. (1981) Inhibition of LH-induced ovarian androgen biosynthesis by LHRH in vitro. Endocrinology 108, Suppl. p. 89, Abstr. 25.

Main, S.J. \& Setchell, B.P. (1980) Responsiveness of the 
pituitary gland to androgens and of the testis to gonadotrophins following damage to spermatogenesis in rats. J. Endocr. 87, 445-454.

Massicotte, J., Veilleux, R., Lavoie, M. \& Labrie, F. (1980) An LH-RH agonist inhibits FSH-induced cyclic AMP accumulation and steroidogenesis in porcine granulosa cells in culture. Biochem. Biophys. Res. Commun. 94, 1362-1366.

Massicotte, J., Borgus, J.P., Lachance, R. \& Labrie, F. (1981) Inhibition of HCG-induced cyclic AMP accumulation and steroidogenesis in rat luteal cells by an LHRH agonist. J. Steroid Biochem. 14, 239-242.

Means, A.R. (1977) Mechanisms of action of folliclestimulating hormone (FSH). In The Testis, Vol. 4, pp. 163-188. Eds A. D. Johnson \& W. R. Gomes. Academic Press, New York.

Means, A.R., Fakunding, J.L., Huckins, C., Tindall, D.J. \& Vitale, R. (1976) Follicle-stimulating hormone, the Sertoli cell and spermatogenesis. Recent Progr. Horm. Res. 32, 477-527.

Perrin, M.H., Vaughan, J.M., Rivier, J.E. \& Vale, W.W. (1980) High affinity GnRH binding to testicular membrane homogenates. Life Sci. 26, 2251-2256.

Purvis, K., Clausen, O.P.F, \& Hansson, V. (1979) Androgen effects on rat Leydig cells. Biol. Reprod. 20, 304-309.

Reddy, P.V., Azhar, S. \& Menon, K.M.J. (1980) Multiple inhibitory actions of luteinizing hormonereleasing hormone agonist on luteinizing hormone/ human chorionic gonadotropin receptor-mediated ovarian responses. Endocrinology 107, 930-936.

Reeves, J.J., Seguin, C., Lefebvre, F.A., Kelly, P.A. \& Labrie, F. (1980) Similar luteinizing hormone releasing hormone binding sites in rat anterior pituitary and ovary. Proc. natn. Acad. Sci., U.S.A. 77, 5567-5571.

Rich, K.A. \& de Kretser, D.M. (1979) Effect of fetal irradiation on testicular receptors and testosterone response to gonadotrophin stimulation in adult rats. Int. J. Androl. 2, 343-352.

Rich, K.A., Kerr, J.B. \& de Kretser, D.M. (1979) Evidence for Leydig cell dysfunction in rats with seminiferous tubule damage. Molec. cell. Endocr. 13, 123-135.

Rippel, R.H. \& Johnson, E.S. (1976) Inhibition of hCG-induced ovarian and uterine weight augmentation in the immature rat by analogs of $\mathrm{GnRH}$. Proc. Soc. exp. Biol. Med. 152, 432-436.

Risbridger, G.P., Kerr, J.B. \& de Kretser, D.M. (1981) Evaluation of Leydig cell function and gonadotropin binding in unilateral and bilateral cryptorchidism: evidence for local control of Leydig cell function by the seminiferous tubule. Biol. Reprod. 24, 534-540.

Risbridger, G.P., Kerr, J.B., Peake, R.A. \& de Kretser, D.M. (1981) An assessment of Leydig cell function after bilateral or unilateral efferent duct ligation: further evidence for local control of Leydig cell function. Endocrinology 109, 1234-1241.

Seppala, M. \& Wahlstrom, T. (1980a) Identification of luteinizing hormone-releasing factor and alpha subunit of glycoprotein hormones in human pancreatic islets. Life Sci. 27, 395-397.

Seppala, M. \& Wahlstrom, T. (1980b) Identification of luteinizing hormone-releasing factor and alpha subunit of glycoprotein hormones in ductal carcinoma of the mammary gland. Int. J. Cancer 26, 267-268.

Seppala, M., Wahlstrom, T. \& Leppaluoto, J. (1979) Luteinizing hormone-releasing factor (LRF)-like immunoreactivity in rat pancreatic islet cells. Life Sci. 25, 1489-1496.

Sharpe, R.M. (1980a) Extra-pituitary actions of LHRH and its agonists. Nature, Lond. 286, 12-14.

Sharpe, R.M. (1980b) Temporal relationship between interstitial fluid accumulation and changes in gonadotropin receptor numbers and steroidogenesis in the rat testis. Biol. Reprod. 22, 851-857.

Sharpe, R.M. (1982) The hormonal regulation of the Leydig cell. In Oxford Reviews in Reproductive Biology. Ed. C. A. Finn. Oxford University Press (in press).

Sharpe, R.M. \& Fraser, H.M. (1980a) Leydig cell receptors for luteinizing hormone-releasing hormone and its agonists and their modulation by administration or deprivation of the releasing hormone. Biochem. Biophys. Res. Commun. 95, 256-262.

Sharpe, R.M. \& Fraser, H.M. (1980b) HCG stimulation of testicular LHRH-like activity. Nature, Lond. 287, 642-643.

Sharpe, R.M. \& McNeilly, A.S. (1980) Differences between dispersed Leydig cells and intact testes in their sensitivity to gonadotrophin-stimulation in vitro after alteration of LH-receptor numbers. Molec. cell. Endocr. 18, 75-86.

Sharpe, R.M., Fraser, H.M., Cooper, 1. \& Rommerts, F.F.G. (1981) Sertoli-Leydig cell communication via an LHRH-like factor. Nature, Lond. 290, 785-787.

Sharpe, R.M., Fraser, H.M., Cooper, I. \& Rommerts, F.F.G. (1982) The secretion, measurement and function of a testicular LHRH-like factor. Ann. N.Y. Acad. Sci. (in press).

van Beurden, W.M.O., Roodnat, B., de Jong, F.H., Mulder, E. \& van der Molen, H.J. (1976) Hormonal regulation of $\mathbf{L H}$ stimulation of testosterone production in isolated Leydig cells of immature rats: the effect of hypophysectomy, FSH and estradiol-17 $\beta$. Steroids 28, 847-866.

Wahlstrom, T. \& Seppala, M. (1979) Luteinizing hormone-releasing factor-like immunoreactivity in islet cells and insulomas of the human pancreas. Int. $J$. Cancer 24, 744-748.

Wheaton, J.E. (1980) Immunoreactive LHRH in ovine pineal glands. Horm. Met. Res. 12, 314-317.

Ying, S.-Y. \& Guillemin, R. (1979) (D-Trp6-Pro'-NEt)luteinizing hormone-releasing factor inhibits follicular development in hypophysectomized rats. Nature, Lond. 280, 593-595.

Ying, S.-Y., Ling, N., Bohlen, P. \& Guillemin, R. (1981) Gonadocrinins: peptides in ovarian follicular fluid stimulating the secretion of pituitary gonadotropins. Endocrinology 108, 1206-1215. 